\title{
The Practice and Justifications of Plea Bargaining by Hong Kong Criminal Defence Lawyers
}

Kevin Kwok-yin CHENG*

Faculty of Law, the Chinese University of Hong Kong

\begin{abstract}
Unlike Western common-law jurisdictions where plea bargaining has been acknowledged, official discourse in Hong Kong denies the existence of plea bargaining. However, defence lawyers are staunch supporters of its use behind the scenes. Using in-depth, semi-structured interviews with Hong Kong criminal defence lawyers, it was found that lawyers' justifications are based on four main grounds: it is non-coercive because the final decision is left to the accused; negotiations avoid the risks of trials; plea bargaining is a practical solution that is in the best interests of the client and the state; and the courts implicitly tolerate the practice. The findings can be explained by Eisenstein and Jacob's (1991) courtroom workgroup model. The present study seeks to bridge the gap in the literature where plea bargaining has only been discussed predominately in the context of Western common-law jurisdictions.
\end{abstract}

Keywords: plea bargaining, guilty pleas, justifications, defence lawyers, Hong Kong

\section{INTRODUCTION}

Hong Kong is a unique legal jurisdiction. It is a special administrative region of the People's Republic of China, yet it has maintained the common-law system derived from its British colonial days under the framework of "one country, two systems." Its criminal justice system reflects more closely the Western common-law world of England and Wales, Canada, Australia, and New Zealand than that of Mainland China and its East Asian neighbours (with the exception of Malaysia and Singapore).

However, perhaps more adamantly than other common-law jurisdictions, official discourse in Hong Kong denies the existence of plea bargaining. Plea bargaining has been recognized in other common-law jurisdictions such as Australia ${ }^{1}$ and England. ${ }^{2}$ With respect to plea bargaining, the Hong Kong Court of Appeal declared that: "It is of major importance

\footnotetext{
* Kevin Kwok-yin Cheng, JD, PhD, is Assistant Professor in the Faculty of Law, the Chinese University of Hong Kong. His research interests revolve around issues in criminal justice and criminology. His works have appeared in the British Journal of Criminology, Asian Journal of Criminology, and International Journal of Offender Therapy and Comparative Criminology.

1. See e.g. Mack \& Roach Anleu (1995).

2. See e.g. Ashworth \& Redmayne (2010).
} 
that there be no appearance of a defendant striking a bargain with the court. Plea bargaining is not part of our jurisdiction." 3 Indeed, decision-makers in Hong Kong have been accused of:

Shut[ting] their eyes to the dark deal-making behind guilty pleas which is the staple of Hong Kong's criminal justice system ... Had they turned their attention to the broad policy underpinning prosecutorial practice, Hong Kong politicians might have raised questions of the fundamental nature about the legitimacy and fairness of day-to-day practice in the courts. ${ }^{4}$

This paper will show that while there may be no appearance of plea bargaining in Hong Kong, in terms of striking a bargain with the court, plea bargaining between defence lawyers and prosecutors is certainly a practice that is prevalent, and operates behind the scenes. ${ }^{5}$ It is not surprising that the occurrence of plea bargaining is not discussed. After all, there is perhaps not a more controversial issue in the criminal process than plea bargaining. Legal scholars have argued against the practice, asserting that it is unconstitutional and undermines defendants' due process rights, ${ }^{6}$ and the public considers it as an agreement that lets offenders off too leniently. ${ }^{7}$

The idea that the defence and prosecution informally reaches an agreement to provide certain concessions to the accused, likely in terms of dropping certain charges or charging with a lighter offence, in return for a guilty plea, most emphatically gives the appearance of the state and defendant circumventing the adjudication of guilt in the court of law. Moreover, it stands in contrast to the ideals of adversarialness. ${ }^{8}$ In Hong Kong, in particular after its handover back to the People's Republic of China in 1997, there has been a greater emphasis by the government to underscore the notion that the Hong Kong Special Administrative Region possesses a legal system that adheres to the rule of law; distinguishing it from the rest of Mainland China. The Hong Kong government goes as far as to state that:

It has often been said that if Hong Kong people have a defining ideology, it is the rule of law. That is why after 1997, the rule of law has been the focus of considerable attention in Hong Kong and for the international community. ${ }^{9}$

The former Hong Kong Director of Public Prosecution, Grenville Cross, even commented that "plea bargaining has traditionally had few friends in Hong Kong."10 Previous studies from other common-law jurisdictions, however, found defence lawyers to be main

3. $R$ v. Scales [1987], p. 587 (emphasis added).

4. McConville (2007), pp. 382-3.

5. The terms "plea bargaining" and "plea negotiations" will be used interchangeably, as with previous studies. See e.g. Mack \& Roach Anleu, supra note 1.

6. Two of the most staunch American scholars against plea bargaining in the US are Albert Alschuler and Stephen J. Schulhofer. See e.g. Alschuler (1968, 1981); Schulhofer (1994). For opposition to plea bargaining by English scholars, see e.g. McConville (1998).

7. Cohen \& Doob (1989).

8. Michael Jackson, in describing Hong Kong's criminal law, commented: "The adversarial nature of English criminal proceedings and the presumption of innocence have played a significant role in shaping the criminal law as it presently exists" (Jackson, 2003, p. 5). See also Malcolm Feeley, who argued that plea bargaining did not rise at the expense of the adversarial system but that changes in the structure of the criminal process gave rise to plea bargaining in proportion to the adversarial trial. It should be noted that Feeley's view is adopted from a historical perspective of the American justice system; Feeley (1982).

9. Hong Kong Government (2002).

10. Cross (2006). 
supporters of plea bargaining. ${ }^{11}$ This appears to contradict the idealized image of the defence lawyer as a zealous defender and champion of the accused, who would rigorously challenge the state's case in an adversarial trial. ${ }^{12}$

Commentators have attributed the support for plea bargaining by legal practitioners, including defence lawyers, to increasing case-load pressures. ${ }^{13}$ With the vast number of cases that are brought to the criminal courts, there are simply not enough resources for each to be contested in trial. Plea bargaining is therefore an efficient case-management mechanism that allows the prosecution, courts, and defence to dispose of their cases quickly. The heavy case-load rationale was refuted by practitioners working in the criminal courts. ${ }^{14}$ Instead, a more persuasive explanation is the establishment of a guilty plea culture in the criminal justice procedure. ${ }^{15}$ Why is it that defence lawyers support the guilty plea and pleabargaining culture? The courtroom workgroup model ${ }^{16}$ offers a compelling explanation. It will be argued that Hong Kong defence lawyers, like other courtroom actors, including judges and prosecutors, celebrate the use of guilty pleas to increase cost-effectiveness and efficiency, and possess a preference for negotiated outcomes over the risks of contested trials.

Section 2 of this paper will demonstrate, relying on interviews with defence lawyers in Hong Kong, that in the context of Hong Kong's justice system, informal plea bargaining is a (secreted) principle component of daily criminal case disposition. In Section 3, it will be shown that defence lawyers justify the practice of plea bargaining, in fact promote its use, by reaffirming the rhetoric of voluntariness of plea decisions by defendants, highlighting the risks of trial, stressing that plea bargaining is a practical response that provides a win-win solution for clients and for the administration of justice, and highlighting the implicit tolerance of its use by the courts. The focus of this study is on defence lawyers because, as noted, theoretically their roles should be that of advocates, challenging the state's evidence on behalf of their clients. But why is it that they are such staunch supporters of plea bargaining? Overall, this study offers an empirical investigation into the workings of plea bargaining in Hong Kong and sheds light on a guilty plea culture that has been largely overlooked. $^{17}$

\section{RESEARCH METHODOLOGY}

This paper is part of a larger study into the factors that influence defendants' decisions to plead guilty in Hong Kong. The purpose was to construct a picture of the guilty plea process in Hong Kong, something that had not been previously attempted. Like many other

11. For support by English defence lawyers, see Mulcahy (1994). For Australian defence lawyers, see Roach Anleu \& Mack (2001).

12. See e.g. Alschuler (1975).

13. See e.g. Blumberg (1967); Fisher (2004); Langbein (1979).

14. Lynch (1994). See also Heumann (1974), who provides empirical evidence to argue against the case pressure explanation of plea bargaining.

15. McConville, supra note 6, p. 580.

16. Eisenstein \& Jacob (1991).

17. Mulcahy noted that: "Most research on plea negotiations has focused on practices in the USA, where discussion of court communities in general has verged on the obsessive. British contributions to these debates, while significant, have been more modest in number" (Mulcahy, supra note 11, p. 412). This paper adds to the scarce plea bargaining literature in Hong Kong. 
common-law jurisdictions, guilty pleas are the main mode of case disposition in Hong Kong; a trend that seems to be increasing. For instance, from the year 2006 to 2011 the guilty plea rates in the District Court rose from $65.4 \%$ to $76.9 \%$. The District Court is Hong Kong's intermediate criminal court that tries both summary and indictable offences and can impose a maximum penalty of up to seven years' imprisonment. Likewise, in the Court of First Instance (the High Court that tries the most serious criminal offences), the guilty plea rate rose from $68.2 \%$ in 2006 to $76.1 \%$ in $2011 .^{18}$

The research began with courtroom observations and collecting data to discern what variables, including legal variables such as number of charges, type of offence, and evidence, and extra-legal variables such as type of legal representation and demographic characteristics, would affect defendants' plea decisions from 2011 to $2012 .{ }^{19}$ Alas, observations of courtroom proceedings only give an account of the public face of justice. They regrettably do not capture the decision-making that occurs in the pre-trial stages, namely the process of plea bargaining, which, as noted, is purposely hidden. ${ }^{20}$

To remedy this, semi-structured in-depth interviews were conducted with 26 criminal defence lawyers in Hong Kong. In Hong Kong, lawyers tend to practise in more than one area of law, thus only lawyers who indicated they practise in the area of criminal law were recruited for this study. The sample comprised 16 barristers and 10 solicitors, ${ }^{21} 21$ of whom were men and 5 were women. Although this study focuses on defence lawyers, of the sample lawyer group, three were previously prosecutors, two were former police officers, and two had acted as magistrates, so varying views of courtroom actors are represented. Moreover, many defence lawyers are retained by the Department of Justice to act as prosecutors in selected cases on fiat. In addition, in Hong Kong there is not a clear distinction between private and public lawyers. Private practising lawyers are retained by the Duty Lawyer Scheme or Legal Aid Department to act as public lawyers for certain cases. Virtually all the interviewees had experience in both private and public practice.

The interviews ranged from 30 minutes to over two hours, with most lasting for around an hour. Open-ended questions were used, which allowed interviewees to speak more candidly and permitted comparisons between interviews to identify recurrent themes. The interviewees discussed how plea bargaining operated in Hong Kong and their justifications for it. Given that there were no strict interview guidelines, the interviewees were able to discuss a range of issues based upon their experiences and their personal opinions. These comments were analyzed using Scott and Lyman's pioneering concept of justifications, which are construed as accounts where the respondent accepts participation in the act, in this case plea negotiations, but does not accept the negative quality associated with it. $^{22}$

18. These rates were calculated from statistics on convictions and acquittals provided by The Department of Justice (2012). The magistrates' courts rates were not included because the official statistics included bind over orders as acquittals, which I disagree with, thus rendering the guilty plea rates lower. This paper will also discuss how bind over orders fit with plea bargaining. Both the District Court and the Court of First Instance deal with indictable offences.

19. The results of the courtroom observations part of the study are presented in Cheng (2013).

20. Baldwin (2008), p. 384.

21. Following the English legal tradition, Hong Kong continues to possess a dual legal profession where solicitors mainly conduct non-court work whereas barristers are primarily litigators, although in the lower courts both professions may litigate. In this paper, the term "defence lawyers" refers to both solicitors and barristers.

22. Scott \& Lyman (1968). 


\section{THE PRACTICE OF PLEA BARGAINING IN HONG KONG}

\subsection{Plea Bargaining Terminology}

It is not just the practice of plea bargaining, even the term "plea bargaining" carries with it a lot of adverse connotations in Hong Kong. Before proceeding, it is important to define what is meant by plea bargaining or plea negotiations, because definitions of what it entails are a matter of contention. When the Court of Appeal stated in Scales that plea bargaining is not a part of Hong Kong's jurisprudence, it was referring to:

[A]n indication from a trial judge that if a man pleads guilty he/she will get one sentence and if he/she does not, and is convicted after trial, he/she will get another more severe one. ${ }^{23}$

Here, the court is talking about judges' involvement in plea negotiations and, in particular, its role in guaranteeing certain sentences in return for a guilty plea. ${ }^{24}$ Indeed, any advanced sentence indications from the courts are prohibited in Hong Kong. ${ }^{25}$ Under the Basic Law, the previous common law in Hong Kong and its legal principles prior to 1997 were maintained after the handover ${ }^{26}{ }^{2}$ With respect to pleas, Hong Kong continues to adhere to the Turner guidelines that forbid sentence indications. Sentence indications from judges were regarded as improper pressure on the accused to plead guilty. In 2005, the landmark English case of Goodyear now permits judges to provide advanced sentence indications in England $;{ }^{27}$ this was not adopted in Hong Kong.

In this paper, the focus will be on the operations of plea bargaining that take place between defence lawyers and prosecutors that result in changes with respect to charges in return for the defendant(s) pleading guilty. Following the English legal system, and unlike many US jurisdictions, prosecutors in Hong Kong cannot recommend sentences to judges and judges do not simply follow prosecutors' recommendations. ${ }^{28}$

There is a strong emphasis that stresses judicial independence from plea negotiations in Hong Kong and distinguishes Hong Kong from the American system. One senior partner in a prominent solicitors' law firm in Hong Kong readily admitted that plea discussions do occur between defence lawyers and prosecutors in Hong Kong, but was quick to exclude any involvement from judges and contrast it with US-style plea bargaining:

[Negotiations exist] but not in the sense it does in America, because the judge or magistrate does not get involved in it. So plea bargaining takes place between the defence counsel and the prosecutor, but only insofar as charges will be dropped or which charge will be proceeded with

However, while the interviewees were ready to confirm the existence of plea bargaining between defence and prosecution, they noted that it would not be a term that they would use in open court. This is consistent with the directions by the Court of Appeal that ensured there be no appearance of plea bargaining. Another barrister stated that he would never use the terms "plea bargaining" or "plea negotiations" in court:

I know it's used in America a lot, plea negotiations, plea bargaining ... The prosecution virtually in some states tell the judges what the agreement is and how many years in prison he will be

\footnotetext{
23. $R v$. Scales, supra note 3, p. 387.

24. This is different in the US. See Alschuler (1976).

25. Rv. Turner [1970].

26. Art. 8, Basic Law.

27. $R$ v. Goodyear [2005].

28. Young (2009), pp. 121-3.
} 
going to, and the judge just orders what the prosecution says. Obviously we don't have that system here ... The reason why the word isn't really used or used in those terms is because it suggests there could be possibilities of perverting the course of justice. What we call it is make representations. The term I use in court is "I wish to make representations to the Department of Justice to see if this matter can be dealt with in another way."

Clearly, there is a sturdy endeavour to disguise plea bargaining in open court and thereby hide it from the public. Nevertheless, even if it is termed as "making representations," this shows that plea bargaining does exist in Hong Kong. More importantly, it is a practice that the courts know occurs but do not often intervene in. The recognition of the tolerance of plea bargaining, at least in defence lawyers' views, will be examined in more depth later. While there are (unsurprisingly) no official statistics available that show how many guilty pleas are a result of plea bargaining in Hong Kong, the interviews did find that plea bargaining was something that was "frequent," "common," and occurred "daily" in the Hong Kong criminal justice system.

\subsection{How Negotiations are Initiated}

Plea negotiations are always initiated by the defence in Hong Kong. There are two ways that defence lawyers contact the prosecution about plea bargaining. The first is the formal way of writing a letter to the Department of Justice, and making a case that it would be in the prosecution's interest to accept a plea bargain. Primarily this is done through an assessment of the evidence and applying it to the charges that the defendant is facing. ${ }^{29}$ If the defence lawyer finds that in the prosecution's case certain charges are weaker, then the defence lawyer may write to the Department of Justice stipulating this, as one barrister who practises virtually exclusively in criminal law explained:

For instance in some cases, there are several charges, but evidence for one or two charges is weaker, another one or two stronger. Or the defendant has an admission for charge one and two but not three and four. These are in terms of evidence, we would think about them. Maybe we ask them to drop charges three and four and only charge one and two for a guilty plea. If there are many charges, we guess how many they would accept.

Letters to the prosecution may not be a one-off occurrence, rather plea bargaining can be a process that necessitates various letter exchanges until both sides come to a deal. ${ }^{30}$

In writing letters, defence lawyers would assess the case and make their case to the prosecution for a plea bargain. However, not all cases permit so much time for assessment. This is especially true in duty lawyer cases. Duty lawyers are basically public defenders and, in Hong Kong, there are no full-time public defence lawyers. The Duty Lawyer Scheme was set up to provide low-income defendants with affordable legal advice and representation in the magistrates' courts. The scheme is run jointly by the Law Society of Hong Kong and the Hong Kong Bar Association, and is subsidized by the government. Duty lawyers are drawn from a list of private practising solicitors or barristers that assist the scheme in a particular magistrate court for a flat fee. The duty lawyer appears in a particular court for either a full

29. For how defence lawyers assess the evidence before engaging in plea bargaining, see Emmelman (1997). The defence's objectivity in assessing the strength of the case has been challenged, since it is contended that people tend to select facts that best fit their narratives; see Bibas (2004).

30. Debra S. Emmelman contended that plea bargaining involved multiple episodes and is frequently recurring: Emmelman (1996). 
day or half a day. They are assisted by court liaison officers, who are full-time staff of the Duty Lawyer Scheme. Court liaison officers are involved with the administrative duties such as taking defendants' statements. ${ }^{31}$

The problem of the Duty Lawyer Scheme is that the assigned lawyers usually do not meet their clients until just before the court commences. In a particular day, each duty lawyer is responsible for representing multiple cases, as one barrister who essentially acts as a duty lawyer pointed out:

As a duty lawyer, the client comes in that morning and I need to advise instantly ... The duty lawyer won't arrive so early but we would be there at about ten. You can count; I begin seeing defendants at 9 a.m. and have to appear at 10. If I need to do ten cases, on average that would be 5 minutes to 6 minutes. That would certainly not be much.

In terms of plea bargaining, not only do duty lawyers not have time to give the case considerable thought, there is also not enough time to draft a letter to the Department of Justice. Plea bargaining in these situations is conducted more informally, through face-to-face conversations with the acting prosecutor in court and getting approval by telephone. Another solicitor described this form of informal plea bargaining:

You keep making phone calls. Stand down the case. Send it immediately upstairs to the office. [The Department of Justice] has an administrator, a prosecutor that makes phone calls ... If [the plea bargain] is accepted, call back. At times it is hasty like that ... It's very fast and it's not formal.

If a plea bargain is accepted, then the prosecution would amend the charges quickly and the case would be processed in court on the same day. Although plea bargaining may be more hurried for duty lawyers, regardless of whether they are acting privately or on behalf of the Duty Lawyer Scheme, defence lawyers held the same views towards plea bargaining in Hong Kong.

\subsection{Types of Plea Bargain}

As discussed, the prosecution can revise charges after plea negotiations with the defence. ${ }^{32}$ The most common form of plea bargaining in Hong Kong is therefore charge bargaining. Charge bargaining typically takes two forms: dropping certain charges in multiple-charge cases or reducing a charge to a lesser offence. Dropping charges occurs in the situation described above, where the accused is faced with multiple charges, and in exchange for guilty pleas on certain charges, the prosecution agrees to drop the other ones. The second form of charge bargaining ensues when a certain charge is replaced with a lighter charge. Most criminal offences are defined along a spectrum of severity, such as from common assault to assault causing grievous bodily harm, and from drug possession to drug trafficking. Prosecutors can drop a charge to a lesser one, as one barrister illustrated this type of charge bargaining in a typical case of assault:

You go to the prosecutor and say your case is wounding, all outer layers broken, but it may only be a scratch ... If you charge with assault occasioning actual bodily harm, I will plead. But if you

31. Lo (2009), pp. 140-2.

32. Art. 63 of the Basic Law confers all powers to prosecute to The Department of Justice. The Prosecution Code require prosecutors to consider the "sufficiency of evidence" and "the public interest" when deciding to prosecute or not. Nonetheless, prosecutors have a large amount of discretion with respect to charges: Department of Justice (2013). 
charge with wounding, I'll fight it. The prosecution may consider that it'll need to dispense a lot of resources on such a small difference.

Here, the facts of whether the act that occurred is enough to constitute wounding under criminal law are contested by the defence. However, instead of challenging the prosecution's charge in trial, the defence may concede to the lesser charge of assault occasioning actual bodily harm, which would result in a lighter sentence by the court. Therefore the defence would strike a deal with the prosecution and have the defendant plead guilty.

Another type of plea bargaining, that occurs mainly in the US is sentence bargaining. This occurs when the prosecutor guarantees certain sentences for a defendant who pleads guilty. Prosecutors cannot do so in Hong Kong, and the only thing that they can do is recommend certain sentences or promise not to object to the defence's sentence recommendation to the court. ${ }^{33}$ But the final sentence is always left in the hands of the judges. However, charges are related to sentences, so through charge bargaining, both the defence and the prosecution are fairly certain that plea bargaining would result in a more lenient sentence. One barrister who almost exclusively practises criminal law said:

We will have looked at the charges. We will know the ball park figure of the sentence after conviction at trial ... In other charges there may be precedents. For example, breach of condition of stay, the Court of Appeal has said 15 months etc. These are more commonplace so we would know.

Because of precedents, sentencing guidelines in these cases, and general experience, controlling the charges can effectively control sentences as well. ${ }^{34}$ A further type of plea bargaining is fact bargaining. This is where the prosecution amends the facts of the case to reduce its aggravating features. By so doing, the accused would be perceived better by the court and receive a more lenient sentence.

A final type of plea bargain is the bind over order. A bind over order is typically not considered as a type of plea bargain because defendants do not actually plead guilty to them. The prosecution can be asked by the defence, and less commonly invited by the court, to offer no evidence against the accused's case if the defendant agrees to be bound over to keep the peace and/or be of good behaviour. ${ }^{35}$ The accused must admit to committing the offence in accordance with the facts of the prosecution's case before the court. In order to bind over the defendant, the court must be precise about what acts the defendant is prohibited from doing and the duration of how long that prohibition lasts. ${ }^{36}$ For example, if the case in question was an assault, then the terms of the bind over order would be to refrain from further acts of violence, including the threat of violence for a period of time. ${ }^{37}$ If the defendant breaches the order, then a fine would be levied upon him/her. The main benefit for the accused is that, because no plea is entered, and the prosecution offers no evidence, even if the accused admitted to wrongdoing there would be no criminal record. Bind over orders are

33. Young, supra note 28, p. 122.

34. A good resource for sentencing indications is Cross \& Cheung (2011). Robert E. Scott and William J. Stuntz noted that experienced lawyers have good estimations of "market prices" for various types of case: Scott \& Stuntz (1992), p. 1923.

35. Department of Justice, supra note 32. The power of the court to bind someone over is derived from s. 109I Criminal Procedure Ordinance (Cap. 221).

36. Lau Wai Wo v. HKSAR (2003).

37. From the courtroom observations, a bind over order typically lasts for 12 months. 
mainly used for minor offences such as fighting in a public place. There is, however, a lack of a standard in when to proceed with a bind over, and it is often left up to negotiations between the defence and prosecution. Hence, the prosecution's decisions to proceed with a bind over order have caused controversies in Hong Kong. ${ }^{38}$

\section{THE JUSTIFICATIONS FOR PLEA BARGAINING}

\subsection{Clients' Voluntariness}

One main justification for the practice of plea bargaining by defence lawyers is that it is noncoercive, and that guilty pleas are a result of their clients' voluntary choice. Assurance of voluntariness was underscored in the Turner guidelines and subsequently reiterated in Hong Kong case-law. ${ }^{39}$ If a plea is found to have resulted from improper pressure, then it would be treated as void by the courts. ${ }^{40}$ From the courtroom observations though, the courts do not ask whether the defendant pleads guilty voluntarily in each plea arraignment. Past studies raised concerns that it is the defendants' own legal representatives who pressure them into pleading guilty in the English criminal justice system. ${ }^{41}$ This is clearly something that Hong Kong criminal defence lawyers want to avoid being perceived as doing. This point was stressed by one barrister, who said:

To plead guilty or not is [the client's] decision, no one can make that decision for him. Barristers can give him advice such as a $90 \%$ chance that you will lose. That's the advice you give him, but he has a right to not accept ... The court and no one else would blame us for following instructions, because the system, the society needs someone to follow defendants' instructions. This is their mandate from heaven. We cannot take it away and must respect that.

The way that defence lawyers in Hong Kong asserted that they do not pressure defendants into pleading guilty is by defining their role as lawyers as mere advisors to their clients. In other words, they did not consider substantive guilt or the defendants' moral culpability, ${ }^{42}$ and only acted in accordance with their client's instructions. Another barrister remarked that he did not venture into asking whether his clients actually committed the alleged offence(s):

It is not my role to know. I don't need to know. I just follow my instructions to act. The court is not here to find out the truth, this is an ideal. It can only take the evidence of both sides and decide. Similarly, my role is to follow my client's instructions. Whatever happens in the background, firstly, I'm not in a position to investigate; and secondly, that's not my role. Even if that's my role, I don't have the ability to investigate. No matter what, I don't need to consider these things. All I need is your story, and retell your story in court.

By emphasizing that they act only as advisors and follow instructions, defence lawyers distance themselves from any potential allegations of them pressuring their clients to plead guilty. Both solicitors and barristers contended that they are abiding by their roles as set out by their respective professional codes of conduct. McConville, however, argued that these

38. Young, supra note 28 .

39. Rv. Lam Yin [1995].

40. Ibid.

41. See Baldwin \& McConville (1977); McConville et al. (1994); Zander \& Henderson (1993).

42. This is distinct from findings in a study of English defence lawyers, where the justification of plea bargaining was attributed to perceptions of the defendants' substantive guilt. See Mulcahy, supra note 11. 
codes of conduct shifted the weight onto defendants and alleviated defence lawyers of ethnical responsibility through reiterating that lawyers act only on their clients' wishes. ${ }^{43}$

What the professional codes do allow for is advice by the defence lawyer in "strong terms." ${ }^{44}$ For instance, The Hong Kong Solicitors' Guide to Professional Conduct (1998) stipulates that: "Advice must be given in a strong and persuasive manner but the client must be left with the clear understanding that he has the right to choose how to plead and whether to give evidence." 45 While the guide to professional conduct highlighted the voluntary decision by the defendant in deciding to plead guilty or not as the final decision, in reality defendants are dependent on the advice of their professional legal representative. It is thus imperative that lawyers consider carefully their advice in recommending a plea. ${ }^{46}$ The Hong Kong Bar Association's Code of Conduct (2012) goes into more detail, and states:

For the purposes of giving proper advice, Counsel is entitled to refer to all aspects of the case where appropriate he may advise his client in strong terms that he is unlikely to escape conviction and that a plea of guilty is generally regarded by the Court as a mitigating factor. ${ }^{47}$

The last point regarding how a plea is regarded as a mitigating factor is vital. In Hong Kong, a plea is presumed to be an indication of the defendant's remorse, and as a response, a onethird sentence discount is given to all guilty pleaders. ${ }^{48}$ Defence lawyers are required to point out the sentence discount to their clients. ${ }^{49}$

\subsection{The Undesirability of Contested Trials}

The second justification for plea bargaining by defence lawyers is the undesirability of electing for trial. In trials there is a risk of conviction and, as mentioned, the defendant faces a harsher penalty compared with pleading guilty. Recently, in Hong Kong there has been controversy regarding the high conviction rates by the courts. The controversy began when senior counsel and editor of Archbold, Clive Grossman, wrote in the preface of the 2010 edition of Archbold Hong Kong that the rate of convictions in Hong Kong's courts was "probably approaching that of North Korea," and that "any person who is arrested on a serious or relatively serious charge is almost certain to be convicted, and since the convictions are in the district and high courts, imprisonment is almost always the norm." course, such a statement was not met with a positive response from the government, which contended that there were no bases for such an accusation. ${ }^{51}$

The interviewees in the present study were divided upon whether a near universal conviction rate existed in Hong Kong. Some defence lawyers praised Grossman's statements as

43. See McConville, supra note 6.

44. This is also permitted and encouraged under the Turner guidelines.

45. Principle 10.16, Commentary 2.

46. Bridges (2006).

47. Para. 150(a).

48. Cross \& Cheung, supra note 34. The one-third discount is even given to defendants who plead guilty at the start of their trial. This is different from in England, where there is a sliding scale of discount depending on at which stage the defendant pleads guilty. See Sentencing Guidelines Council (2007).

49. See Blake \& Ashworth (2004), p. 179. McConville et al., in their observational study of defence lawyers in England, found that defence lawyers generally persuade their clients to plead guilty: McConville et al., supra note 41.

50. Grossman (2009), p. xi.

51. Former Chief Justice Andrew Li denounced the comments as "intemperate outbursts by the author": Wong (2009). 
uncovering the truth about the real operations of Hong Kong's justice system. One barrister went even further and said that the North Korea comparison was not disapproving enough:

My views are that ... I wouldn't have used North Korea, I would've used ... The Israeli military courts that prosecute Palestinians, I think have higher acquittal rates than the District Court and the magistracies. The conviction rates have been far too high.

Others disagreed and believed that the whole matter was overblown. As one senior partner at a solicitor's law firm remarked: "That's rubbish. I mean, that's total, total nonsense, all that ... I thought using North Korea is complete nonsense."

Furthermore, defence lawyers do not know which magistrate or judge will be assigned to their case after they elect for trial. But Hong Kong is a comparatively small legal jurisdiction where legal practitioners tend to know each other, and know of each other's habits. Judges have therefore established certain tendencies as being lenient or prosecution minded. Although defence lawyers claimed that the judge or magistrate was not a consideration in advising a guilty plea, who they were appearing before made the risk of conviction even greater. One barrister noted that: "It can be a factor, but you don't want to pressurize a client into making a decision just based on who your tribunal is. Personally, you'd feel it yourself ... ." Another barrister referred to electing for trial as entering "the judicial lottery."

It is often difficult to argue cases before a judge that is prosecution minded. The interviewees particularly cited cases when their clients had admitted the crime to the police under caution. Legally, it is permissible for the defence to fight a confession in a process known as the voir dire. ${ }^{52}$ In the voir dire, or alternative procedure as it is known in the magistrates' courts and the District Court, the defence can challenge the admissibility of a confession statement. ${ }^{53}$ In practice, however, defence lawyers pointed out that it is difficult to succeed, as one barrister elaborated:

Unless there's evidence of physical abuse or it's videotaped, [confessions are] very difficult [to challenge]. Any sensible lawyer, if they get to the police station, would advise their clients to say nothing. Most people are convicted because of statements made to the police in the absence of lawyers ... Cops are ruthless and some of them are good interrogators. ${ }^{54}$

These risk factors from trial make plea bargaining more desirable, since the outcome is easier to predict. Because of sentencing guidelines and the assurance of the sentence discount, defence lawyers know what to expect from plea negotiations. While judges are not involved in the plea-bargaining process, they rarely reject the charges or a bind over order that has been set by the prosecution. ${ }^{55}$

\subsection{A Practical Approach}

Plea bargaining was emphasized by the defence lawyers interviewed as a practical approach, a welcome alternative to the rigidness of the adversarial trial, that results in a win-win situation for the defendant and for the state. For the defendant, just being caught up in the

52. See Knight \& Upham (2011).

53. The challenge is based upon the test of voluntariness: DPP v. Ping Lin [1976]; Ibrahim v. R [1914].

54. It is not surprising that empirical studies found that defendants who have made a confession are more likely to plead guilty. See e.g. Cheng, supra note 19.

55. This preference for certainty from plea bargains compared with trials has also been cited by English defence lawyers in previous studies. See Mulcahy, supra note 11. 
criminal process can be a daunting and stressful experience. ${ }^{56}$ A defendant would be interrogated by the police, have to spend time and resources hiring a lawyer, some may even be remanded in custody ${ }^{57}$ before they are presumed guilty, and face the prospect of punishment if convicted. A plea bargain, in turn, helps the accused to get a lesser sentence and, perhaps more importantly, avoids the wait for trial and disposes of the case quickly. One criminal defence barrister remarked:

A lot of times, clients want to get the matter over with quickly. Forget the hassle ... And when you are fighting [a trial], there is financial stress, or for a person, when you have something that's incomplete, it may take a long time, several weeks, the stress is high. You may not want to do so many things.

In many cases, the sentence becomes secondary to ending the case expediently. This is especially true for minor offences where the sentence usually results in a fine. ${ }^{58}$

Bind over orders are even better. As noted, the biggest benefit of being bound over is the absence of a criminal record. ${ }^{59}$ Often, defence lawyers would appeal to the compassion of the prosecutor to get the prosecutor to agree to accept a bind over order. One defence counsel explained:

You gotta weep a bit and say, "look, this client, you know, he's got an aged mother, and don't know what he was doing, so give him a bind over" or something like that ... For instance, you get a case where young man is caught with a few grams of marijuana or something like that, the prosecutor might think to himself, or you might say to the prosecutor, "look, if you prosecute the guy, he's going to lose his career ... so give him a chance. $" 60$

The bind over order is considered as a chance for the defendant to escape conviction and face a very light penalty for admitting to committing the alleged offence. In fact, if the accused abides by the conditions of the bind over order, there are no penalties, as the court will only fine the defendant if the order is breached.

When asked whether plea bargaining undermined the due process right and adversarial system that official discourse in Hong Kong claim that it aspires to, one barrister was quick to refute this and reframed the issue by pointing back to the practical benefits that plea negotiations offered:

You academics easily fall into black and white scenarios. It's plead guilty or plead not guilty and there's two simple choices. Within it, there involves many factual issues, not just factual issues of a case, that's one level. There are also familial factors. For a client, he may think he didn't do it. If the case gets him bankrupted and breaks his family apart, and he maintains to plead not guilty, is that the best thing for him? Of course, overall in terms of justice, you must fight for justice. But for one person, this can ruin his life. He spends all his time and money. I don't think there's much reason to do that. Maybe I'm [laughs] more pragmatic.

The issue revolving around plea bargaining has been reframed into the triumph of pragmatism over pursuing the ideals of adversarial justice. Lawyers define the best deal for clients

56. See Feeley (1979).

57. Defendants denied bail were also found to be more likely to plead guilty than defendants granted bail. See Kellough \& Wortley (2002).

58. Feeley, supra note 56.

59. For adverse consequences of having a criminal record, see Chui \& Cheng (2013).

60. Under the Statement of Prosecution Policy and Practice, prosecutors must consider the age and character of the accused in deciding whether to accept a bind over order. 
and acting in the best interests of their clients as reducing the costs to them, measured in terms of both reduction in sentence and minimization of resources spent in contesting the criminal case. ${ }^{61}$ The notion of guilt or innocence is not a concern for defence lawyers, and their objective is about securing a good deal.

In addition to benefiting the individual defendant, defence lawyers underscored the benefits of plea bargaining for the administration of the criminal courts as well. Another barrister commented, after being asked about the desirability of plea bargaining:

Good or not? ... I think it's good. It's a mechanism that makes the system efficient. I think there's a reason for its existence, since in America and Britain or other common law systems, this mechanism exists. If you ask why it exists, then I haven't looked deeply into this. But I think this is a mechanism that makes the system more efficient. You won't need to go to trial for every charge, regardless of its seriousness. Especially in a small place like Hong Kong, there are a lot of offences every day. There's no way that every offence goes to trial, the legal system would be bogged down.

The key thing for defence lawyers is how plea bargaining preserves efficiency, and that the court system, as originally intended with trials as the main mode of case disposition, is unsustainable. Plea bargaining is therefore a response that maintains the otherwise unsustainable criminal justice system.

The courts in Hong Kong would certainly concur with this objective, although they would likely never publically endorse plea bargaining. Bokhary JA, when highlighting the advantages of guilty pleas for the courts in general, said:

[A] guilty plea removes the question of guilt or innocence from the considerations of the courts ... So it does bring about some certainty and finality. And even a very late plea does save some time even if not as much as it would have saved had it came earlier. ${ }^{62}$

Defence lawyers, aside from justifying plea bargaining to be in the client's best interests, also justified plea bargaining based on efficiency, in that it assists the court system. Although the defence lawyer is commonly perceived as the sole agent in the criminal justice system that is on the side of the accused, defence lawyers are officers of the court ${ }^{63}$ as well and are interested in assisting the administration of the courts instead of challenging the state's case regardless of its efficiency. ${ }^{64}$ There is a commodification of the criminal procedure where cases are processed from the perspective of system efficiency. ${ }^{65}$

\subsection{Implicit Tolerance}

The final justification by defence lawyers for plea bargaining was that the practice, while not discussed openly, was implicitly tolerated by the courts. Whether it is a charge bargain or a bind over order, it is uncommon for a judge or magistrate to question the arrangement made between the defence and prosecution beforehand. From the perspective of defence lawyers, they believe

61. Peter W. Tague argued that defence lawyers advise clients to plead guilty not out of selfish interests, since it would be more selfish to recommend trials because it would maximize remuneration by lengthening the case. See Tague (2007).

62. Rv. Chan Chi-sing [1995].

63. See Gaetke (1989).

64. Blumberg argued that defence lawyers acted as double agents who acted for defendants as well as the court organization: Blumberg, supra note 13.

65. McConville, supra note 6, p. 581. 
that the role of the court is to act as a neutral arbitrator and not intervene in a plea bargain, which is in the domain of the defence and prosecution. For instance, one barrister explained:

It would be very rare for a judge or magistrate to second guess or refuse to accept a plea bargain, you know. But that assumes that all parties are carrying out their duties ... I think the judge or magistrate would say, "Oh, the prosecutor has made a decision. It's no business of mine to tell the prosecutor how to do their work." Because then, they lose their independence and become a second prosecutor.

Similarly, another barrister pointed out how, from his experience, a court seldom interferes with a plea bargain struck between the defence and prosecution. When asked whether judges affect plea bargaining in Hong Kong, the barrister replied:

No. It is because the decision of a plea bargain is made by both the prosecutor and defence sides. In bind over orders they may have a little influence because the judge has the power of rejecting a bind over order ... However ... It is rare. If the prosecutor's side allows a bind over, they have generally undergone through considerations.

In other words, even though the court theoretically has the power to reject a plea bargained agreement, in reality, judges and magistrates do not really question the decision made by counsel on both sides.

Indeed, in the rare occurrences where the court has questioned plea bargain arrangements, mainly for bind over cases, defence lawyers regard such actions as going against the norm even if the court has the authority to do so. One barrister criticized the judges who probe into deals made between the defence and prosecution. As he remarked:

There are some personalities who want to enter the arena ... One individual [judge], would say, "Why are you binding over this person but not for other people?" It's not that he doesn't have a valid point ... But when it's your case, and you're up with a document for a bind over, you just want to quickly get out of court as fast as possible ... That is theoretically correct, however, don't delay my client, don't you know, affect my client ... the prosecution is happy and the defence is happy, you shouldn't concern yourself ... You're not in charge of the prosecution. Judges become sort of "this is my court, everything here I control." They forget, I believe, what their real role is and become too empowered in trying to control too much.

Again, the theme of the desirability to dispose of criminal cases efficiently is underscored. Judges who intervene with respect to plea bargaining are regarded as hampering the effective administration of the justice system. For the most part, defence lawyers contend that the court knows of the behind the scenes plea negotiations but allows them to be processed in open court.

However, there are still concerns about this implicit tolerance by the courts that should be underlined. The implicit tolerance of plea bargaining by the courts leads to the danger of a lack of judicial oversight over plea bargaining, where defendants may be pressured to make a deal so that they can end the proceedings as soon as possible and receive a lighter sentence. It also grants the prosecution too much power in deciding the outcome of cases, which may lead to possibilities of overcharging to get the accused to plead to fewer charges.

\section{CONCLUSION}

This paper has demonstrated how plea bargaining is practised in Hong Kong, and the justifications of this controversial practice by criminal defence lawyers. Plea negotiations between defence lawyers and prosecutors are a daily aspect of the criminal process in Hong 
Kong, but are designed to be veiled from public scrutiny and disclosure in the open court. But, as shown in this paper, it certainly does occur, but disguised in the terminology of "making representations to the prosecution." Plea bargaining is always initiated by the defence, either through written letters or verbal agreements, and because there is an absence of judicial involvement, plea bargaining in Hong Kong mainly takes the form of charge bargaining and the bind over order. The defence lawyers interviewed justified plea bargaining on three main grounds: its lack of coerciveness because final plea decisions come from defendants; the undesirability of risking a trial; and providing sensible outcomes that are in fact in the best interest of the clients and also of the court system.

The practice and justifications of plea bargaining in Hong Kong can be explained by the courtroom workgroup model. The model contends that, instead of an adversarial relationship, informal arrangements are made between defence lawyers, prosecutors, and the court to work together as collaborators. So, as opposed to challenging the prosecution's case every step of the way, defence lawyers work towards the same goals of the efficient disposal of criminal cases, control over case outcomes, and maintenance of a collegial relationship. Through plea bargaining, as has been shown, defence lawyers and prosecutors can reduce the uncertainty of case outcomes and arrive at their own decision as to what sentence a defendant should receive. Although prosecutors cannot guarantee sentences in Hong Kong, they can control the charges, and that gives both the prosecution and defence a good estimate of what sentence a defendant will get. This collaborative atmosphere may be exacerbated by the small circle of legal professionals in Hong Kong. Even amongst the sampled defence lawyers, many have previously worked as prosecutors on behalf of the Department of Justice, and some were even former full-time prosecutors and magistrates. Defence lawyers in Hong Kong often switch between acting as appointed public lawyers and private lawyers, and could easily develop relationships with prosecutors and judges stationed in the relatively few courts in Hong Kong.

Nonetheless, there are obvious concerns. The most crucial risk is that, through plea bargaining, defence lawyers' working relationships with prosecutors would lead to innocent defendants pleading guilty. ${ }^{66}$ Any ideas that only guilty defendants plead guilty are simply dangerous assumptions. ${ }^{67}$ This is particularly true when defence lawyers advise their clients that a guilty plea will result in a sentence discount. Not only do plea bargaining and sentence discounts increase the probability that innocent defendants plead guilty, it also absolves the prosecution from having to prove its case in a contested trial, which is a staple of the adversarial system. Through plea bargaining, the defendants' rights, specifically the right to a fair trial, ${ }^{68}$ are also forfeited. ${ }^{69}$

Through the study of plea bargaining in Hong Kong, this paper has shed light on this largely hidden practice, and presented an intriguing paradox. Plea bargaining is veiled from

66. See the exchange between McConville \& Bridges (1993) and Zander (1993). See also Sanders et al. (2010), in particular the section entitled "Do the Innocent Plead Guilty? (Is the Pope a Catholic?)," pp. 486-9.

67. A recent experimental study found that innocent defendants were ready to admit guilt if they could secure some benefit: Dervan \& Edkins (2013).

68. Art. 87, Basic Law.

69. Andrew Ashworth and Mike Redmayne argued that the sentence discount runs contrary to the spirit of four fundamental rights of the accused: the presumption of innocence; the privilege against self-incrimination; the right not to be discriminated in exercising one's rights; and the right to a fair and public hearing: Ashworth \& Redmayne, supra note 2, pp. 312-16. 
public scrutiny in Hong Kong because it presumably would jeopardize Hong Kong's image of a legal system that adheres to the rule of law and due process. Yet defence lawyers, while acknowledging the attempt to keep plea bargaining concealed, justify plea bargaining as beneficial. In particular, they assert that plea bargaining serves to act in the interests of defendants and the court system, while at the same time undermining the desire to test the state's case in trial. This study has demonstrated that the existence of a guilty plea culture is not limited to Western common-law jurisdictions, where McConville acutely observed:

[The] bargained-for-plea is no longer claimed to be aberrational, an object of shame and apology. Instead, it has come in from the cold to be celebrated as an ornament of the adversary system, as a jewel in its crown. ${ }^{70}$

The difference in Hong Kong is that plea bargaining is not openly celebrated, but rather its continued practice is commended behind the scenes.

A limitation of this study is the reliance on interviews with a sample of criminal defence lawyers in Hong Kong only, therefore limiting its generalizability. As with all qualitative research with a limited sample, the findings may not be applicable to the entire legal profession in Hong Kong. However, while there are some differences in opinions, namely with regards to the conviction rates controversy in Hong Kong, it is not anticipated that the practice and views of plea bargaining will differ too greatly amongst defence lawyers in Hong Kong.

As Hong Kong continues to pride itself on a legal system that adheres to the rule of law, and as one of the few common-law jurisdictions in Asia, it is important for plea bargaining to be openly debated and discussed. The worse thing that can happen is for plea bargaining to remain a veiled practice. Nothing brings more distrust of the justice system than a lack of transparency and deliberate secrecy.

\section{REFERENCES}

Alschuler, Albert (1968) “The Prosecutor's Role in Plea Bargaining.” 36 University of Chicago Law Review 50-112.

Alschuler, Albert (1975) “The Defense Attorney's Role in Plea-Bargaining." 84 Yale Law Journal 1179-313.

Alschuler, Albert (1976) "The Trial Judge's Role in Plea Bargaining." 76 Columbia Law Review 1059-154.

Alschuler, Albert (1981) “The Changing Plea Bargaining Debate.” 69 California Law Review 652-730.

Ashworth, Andrew, \& Mike Redmayne (2010) The Criminal Process, 4th edn., Oxford: Oxford University Press.

Baldwin, John (2008) "Research on the Criminal Courts," in R.D. King \& E. Wincup, eds., Doing Research on Crime and Justice, 2nd edn., Oxford: Oxford University Press, 375-98.

Baldwin, John, \& Mike McConville (1977) Negotiated Justice: Pressures to Plead Guilty, London: Martin Robertson.

Bibas, Stephen (2004) "Plea Bargaining Outside the Shadow of Trial." 117 Harvard Law Review 2463-547.

Blake, Meredith, \& Andrew Ashworth (2004) "Ethics and the Criminal Defence Lawyer." 7 Legal Ethics 167-89.

Blumberg, Abraham (1967) "The Practice of Law as Confidence Game: Organizational Cooptation of a Profession." 1 Law \& Society Review 15-40.

70. McConville, supra note 6, pp. 580-1. 
Bridges, Lee (2006) "Ethics of Representation on Guilty Pleas." 9 Legal Ethics 80-100.

Cheng, Kevin K. (2013) "Pressures to Plead Guilty: Factors Affecting Plea Decisions in Hong Kong's Magistrates' Courts." 53 British Journal of Criminology 257-75.

Chui, Wing Hong, \& Kevin K. Cheng (2013) "The Mark of An Ex-Offende: Perceived Discrimination and Self-Stigma of Young Men After Prison in Hong Kong." 34 Deviant Behavior 671-84.

Cohen, Stanley A., \& Anthony N. Doob (1989) "Public Attitudes to Plea Bargaining." 32 Criminal Law Quarterly 85-109.

Cross, Grenville I. (2006) “The Case for Plea Bargaining.” South China Morning Post, 8 September.

Cross, Grenville I., \& Patrick W.S. Cheung (2011) Sentencing in Hong Kong, 6th edn., Hong Kong: LexisNexis.

Department of Justice (2012) "Facts and Figures of the Prosecutions Division," online: <http://www. doj.gov.hk/eng/public/pdf/pd2011/Facts_and_Figures.pdf > (last accessed 8 November 2013).

Department of Justice (2013) "Prosecution Policy," online: <http://www.doj.gov.hk/eng/public/ pubsoppaptoc.html> (last accessed 8 November 2013).

Dervan, Lucian E., \& Vanessa Edkins (2013) "The Innocent Defendant's Dilemma: An Innovative Empirical Study of Plea Bargaining's Innocence Problem." 103 Journal of Criminal Law and Criminology 1-48.

Eisenstein, James, \& Herbert Jacob (1991) Felony Justice: An Organizational Analysis of Criminal Courts, Lanham, MD: University Press of America.

Emmelman, Debra S. (1996) "Trial by Plea Bargain: Case Settlement as a Product of Recursive Decisionmaking." 30 Law \& Society Review 335-60.

Emmelman, Debra S. (1997) "Gauging the Strength of Evidence prior to Plea-bargaining: The Interpretive Procedures of Court-Appointed Defense Attorneys.” 22 Law \& Social Inquiry 927-55.

Feeley, Malcolm (1979) The Process is the Punishment: Handling Cases in a Lower Criminal Court, New York: Russell Sage Foundation.

Feeley, Malcolm (1982) "Plea Bargaining and the Structure of the Criminal Process." 7 Justice System Journal 338-54.

Fisher, George (2004) Plea-Bargaining's Triumph: A History of Plea-Bargaining in America, Stanford, CA: Stanford University Press.

Gaetke, Eugene R. (1989) "Lawyers as Officer of the Court." 42 Vanderbilt Law Review 39-95.

Grossman, Clive (2009) "Preface to the 2010 Edition by the General Editor." in P.J. Bokhary, et al., eds., Archbold Hong Kong: Criminal Law, Pleading Evidence and Preface 2010, Hong Kong: Sweet \& Maxwell Asia, xi.

Heumann, Milton (1974) "A Note on Plea Bargaining and Case Pressure." 9 Law \& Society Review 515-28.

Hong Kong Bar Association (2012) The Hong Kong Bar Association's Code of Conduct, Hong Kong: Hong Kong Bar Association.

Hong Kong Government (2002) "The Rule of Law," online: <www.info.gov.hk/info/sar5/elaw_1. $\mathrm{htm}>$ (last accessed 5 August 2013).

Jackson, Michael (2003) Criminal Law in Hong Kong, Hong Kong: Hong Kong University Press.

Kellough, Gail, \& Scot Wortley (2002) "Remand to Plea: Bail Decisions and Plea Bargaining as Commensurate Decisions." 42 British Journal of Criminology 186-210.

Knight, Christopher, \& Anthony Upham (2011) Criminal Litigation, 3rd edn., Hong Kong: Sweet \& Maxwell Asia.

Langbein, John H. (1979) "Understanding the Short History of Plea-Bargaining." 13 Law \& Society Review 261-72.

Law Society of Hong Kong (1998) The Hong Kong Solicitors' Guide to Professional Conduct, Hong Kong: Law Society of Hong Kong.

Lo, P.Y. (2009) "Legal assistance" in M. Gaylord, D. Gittings, \& H. Traver, eds., Introduction to Crime, Law and Justice in Hong Kong, Hong Kong: Hong Kong University Press, 131-46.

Lynch, David (1994) "The Impropriety of Plea Agreements: A Tale of Two Counties." 19 Law \& Social Inquiry 115-34. 
Mack, Kathy, \& Sharyn Roach Anleu (1995). Pleading Guilty: Issues and Practices. Carlton South, Victoria: Australian Institute of Judicial Administration.

McConville, Mike (1998) "Plea Bargaining: Ethics and Politics." 25 Journal of Law \& Society $562-87$.

McConville, Mike (2007) "Politicians and Prosecutorial Accountability in Hong Kong." 36 Common Law World Review 355-88.

McConville, Mike, \& Lee Bridges (1993) “The Innocent(?) Who Plead Guilty.” 143 New Law Journal $160-4$.

McConville, Mike, Jacqueline Hodgson, Lee Bridges, \& Anita Pavlovic (1994) Standing Accused: The Organisation and Practices of Criminal Defence Lawyers in Britain, Oxford: Clarendon Press.

Mulcahy, Aogán (1994) "The Justification of 'Justice': Legal Practitioners' Accounts of Negotiated Case Settlements in Magistrates' Courts." 34 British Journal of Criminology 411-30.

Roach Anleu, Sharyn, \& Kathy Mack (2001) "Pleading Guilty and Professional Relations in Australia." 22 Justice System Journal 155-84.

Sanders, Andrew, Richard Young, \& Mandy Burton (2010) Criminal Justice, 4th edn., Oxford: Oxford University Press.

Schulhofer, Stephen J. (1994) “A Wake-up Call from the Plea-Bargaining Trenches.” 19 Law \& Social Inquiry 135-44.

Scott, Marvin B., \& Standford M. Lyman (1968) "Accounts." 33 American Sociological Review 46-62.

Scott, Robert E., \& William J. Stuntz (1992) "Plea-Bargaining as Contract." 101 Yale Law Journal 1909-68.

Sentencing Guidelines Council (2007) Reduction in Sentence for a Guilty Plea: Definitive Guideline, London: Sentencing Guideline Secretariat.

Tague, Peter W. (2007) "Barristers' Selfish Incentives in Counselling Defendants over the Choice of Plea." Criminal Law Review 3-23.

Wong, Albert (2009) "Courts' 90 pc Conviction Rate Stirs up Row." South China Morning Post, 15 September.

Young, Simon (2009) "Prosecutions Division of the Department of Justice," in M. Gaylord, D. Gittings, \& H. Traver, eds., Introduction to Crime, Law and Justice in Hong Kong, Hong Kong: Hong Kong University Press, 111-30.

Zander, Michael (1993) "The 'Innocent' (?) Who Plead Guilty." 143 New Law Journal 85-6.

Zander, Michael, \& Paul Henderson (1993) The Royal Commission on Criminal Justice: Crown Court Study (Research Study no. 19), London: HMSO. 